\title{
Palladium-catalysed cyclisation of alkenols: Synthesis of oxaheterocycles as core intermediates of natural compounds
}

\author{
Miroslav Palík ${ }^{1}$, Jozef Kožíšek ${ }^{2}$, Peter Koóš ${ }^{3}$ and Tibor Gracza*1
}

\author{
Full Research Paper \\ Address: \\ ${ }^{1}$ Department of Organic Chemistry Slovak University of Technology, \\ Radlinského 9, SK-812 37 Bratislava, Slovakia, ${ }^{2}$ Department of \\ Physical Chemistry, Slovak University of Technology, Radlinského 9 , \\ SK-812 37 Bratislava, Slovakia and ${ }^{3}$ Georganics Ltd., Koreničova 1, \\ SK-811 03 Bratislava, Slovakia \\ Email: \\ Tibor Gracza* - tibor.gracza@stuba.sk \\ * Corresponding author \\ Keywords: \\ alkenols; cycloetherification; homogeneous catalysis; natural \\ products; palladium
}

\author{
Beilstein J. Org. Chem. 2014, 10, 2077-2086. \\ doi:10.3762/bjoc. 10.216 \\ Received: 08 April 2014 \\ Accepted: 15 August 2014 \\ Published: 03 September 2014 \\ Associate Editor: V. M. Dong \\ (c) 2014 Palík et al; licensee Beilstein-Institut. \\ License and terms: see end of document.
}

\begin{abstract}
The study of Pd-catalysed cyclisation reactions of alkenols using different catalytic systems is reported. These transformations affect the stereoselective construction of mono- and/or bicyclic oxaheterocyclic derivatives depending on a starting alkenol. The substrate scope and proposed mechanism of Pd-catalysed cyclisation reactions are also discussed. Moreover, the diastereoselective Pd-catalysed cyclisation of appropriate alkenols to tetrahydrofurans and subsequent cyclisation provided properly substituted 2,5dioxabicyclo[2.2.1]heptane and 2,6-dioxabicyclo[3.2.1]octane, respectively. Such bicyclic ring subunits are found in many natural products including ocellenynes and aurovertines.
\end{abstract}

\section{Introduction}

Oxaheterocycles of various sizes are found in many different biologically active compounds. Particularly, substituted tetrahydrofuran units are present in a large branch of natural products that display interesting biological properties, such as goniofufurone 1 [1], goniothalesdiol 2 [2], varitriol 3 [3], erythroskyrine 4 [4,5], ocellenynes 5 [6,7], sorangicin A 6 [8], aurovertins 7 [9-12] and epicitreoviridinol 8 [13] (Figure 1).

Over the last decades, an enormous work has been devoted to find an efficient stereoselective route to variously substituted tetrahydrofurans $[14,15]$. Among many described transformations, the metal-catalysed carboetherification reactions [16-18] and intramolecular oxycarbonylations of alkenes [19-21] are of particular importance. Although, many of these synthetic routes have showed their potential, there is still an area for improving the scope and stereocontrol of the new synthetic construction of substituted tetrahydrofurans.

Recently, we have described a novel type of $\mathrm{PdCl}_{2} / \mathrm{CuCl}_{2}-$ catalysed bicyclisation reaction of $\alpha$-O-benzyl-protected 
<smiles>COc1cccc(/C=C/C2OC(C)C(O)C2O)c1CO</smiles>

3<smiles>CC(=O)CC[C@H]1OC(c2ccccc2)C(O)C1O</smiles>

goniothalesdio

2

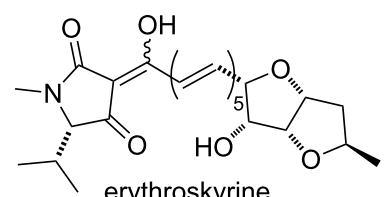

4

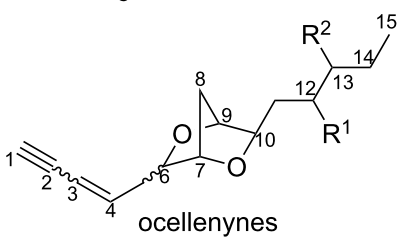

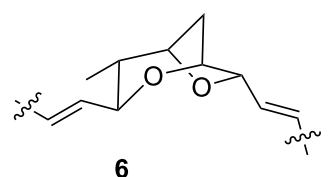

bicyclic subunit of sorangicin A

$E-5 a(E)-\left(6 R^{*}, 7 S^{*}, 9 S^{*}\right), \mathrm{R}^{1}=\mathrm{R}^{2}=\mathrm{Br}$

$Z-5 b(Z)-\left(6 R^{*}, 7 S^{*}, 9 S^{*}\right), \mathrm{R}^{1}=\mathrm{R}^{2}=\mathrm{Br}$

$E-5 c\left(6 S^{*}, 7 S^{*}, 9 S^{*}\right), R^{1}=R^{2}=\mathrm{OH}$

$E-5 d\left(6 S^{*}, 7 S^{*}, 9 S^{*}\right), \mathrm{R}^{1}=\mathrm{OH}, \mathrm{R}^{2}=\mathrm{Cl}$

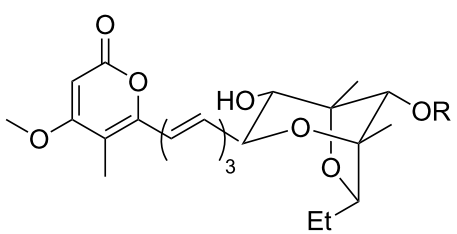

7a aurovertin $B, R=A c$ 7b aurovertin $E, R=H$

\section{Figure 1: Examples of naturally occurring tetrahydrofurans.}

sugar-derived alkenitols A, that provided 2,5-dioxabicyclo[2.2.1]heptanes B with high 1,4-threo-selectivity (Scheme 1) [22,23]. In this process, the terminal carbon-carbon double bond is bis- $O$-functionalised with two hydroxy groups by sequential intramolecular-intramolecular reaction.

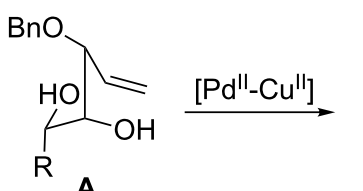

A

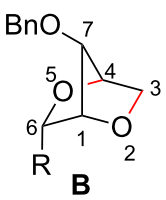

Scheme 1: $\mathrm{PdCl}_{2} / \mathrm{CuCl}_{2}$-catalysed bicyclisation of unsaturated polyols [22].

Based on our continuous interest in the palladium-catalysed cyclisation reactions and their applications in natural product syntheses [24,25], we have decided to explore the substrate scope and the limitations of this transformation. With this aim, we detailed the synthesis of a number of alkene alcohols, and described different catalytic systems in the Pd-catalysed cyclisation reaction. Additionally, we have also outlined the synthetic approach to substituted 2,5-dioxabicyclo[2.2.1] heptane and 2,6dioxabicyclo[3.2.1] octane rings. Such substituted bicyclic rings are of further interest as they are the core substructures in a number of marine derived metabolites, including ocellenynes and sorangicin A.

\section{Results and Discussion Synthesis of starting materials}

Palladium-catalysed cyclisations are substrate selective reactions. In most cases, the literature known cyclisation using similar substrate (with even small change in its substructure) can lead in different product formation. Although, there are several known rules-reactions ( $\beta$-hydride elimination, $\eta^{3}$-complex formation...) which are applicable to predict the behaviour of the used substrate in the Pd-catalysed reaction, there are cases where the results of such reactions still remain on experimental findings.

While the cyclisation reactions of alkenols have been relatively well described in the literature, only less attention was given to the reactions of unsaturated polyols. However, such cyclisations can provide a variety of products which are useful intermediates in many natural product syntheses. With this aim, we have designed syntheses of several substrates bearing different double bonds and substituents to cover certain possibilities for Pd-catalysed cyclisation screening.

At first, easily accessible $\mathrm{C}_{5}$-alkenitols (Figure 2) were chosen as simplest suitable substrates for screening the optimal reaction conditions of the previously described bicyclisation reaction. Thus, the known triols erythro-9 [26] and threo-10 [27] were prepared from divinylcarbinol using asymmetric epoxidation [28,29]. Diastereomeric mixtures of 3-O-benzyl 11, 3-Osilyl-protected 12 and fully unprotected triol 13 was prepared starting from 1,2-O-isopropylidene-D-glyceraldehyde using described procedures [30].<smiles>C=CC(O)C(O)CO</smiles><smiles>C=CC(O)C(O)CO</smiles><smiles>C=CC(O)C(O)CO</smiles>

erythro-9

threo-10

$11 \mathrm{R}=\mathrm{Bn}$

$12 \mathrm{R}=\mathrm{TBS}$

$13 \mathrm{R}=\mathrm{H}$

Figure 2: Structures of $\mathrm{C}_{5}$-alkenitols.

The preparation of substrates $\mathbf{2 0 - 2 3}$ having a symmetrically disubstituted $\mathrm{C}-\mathrm{C}$ double bond is depicted in Scheme 2. The 


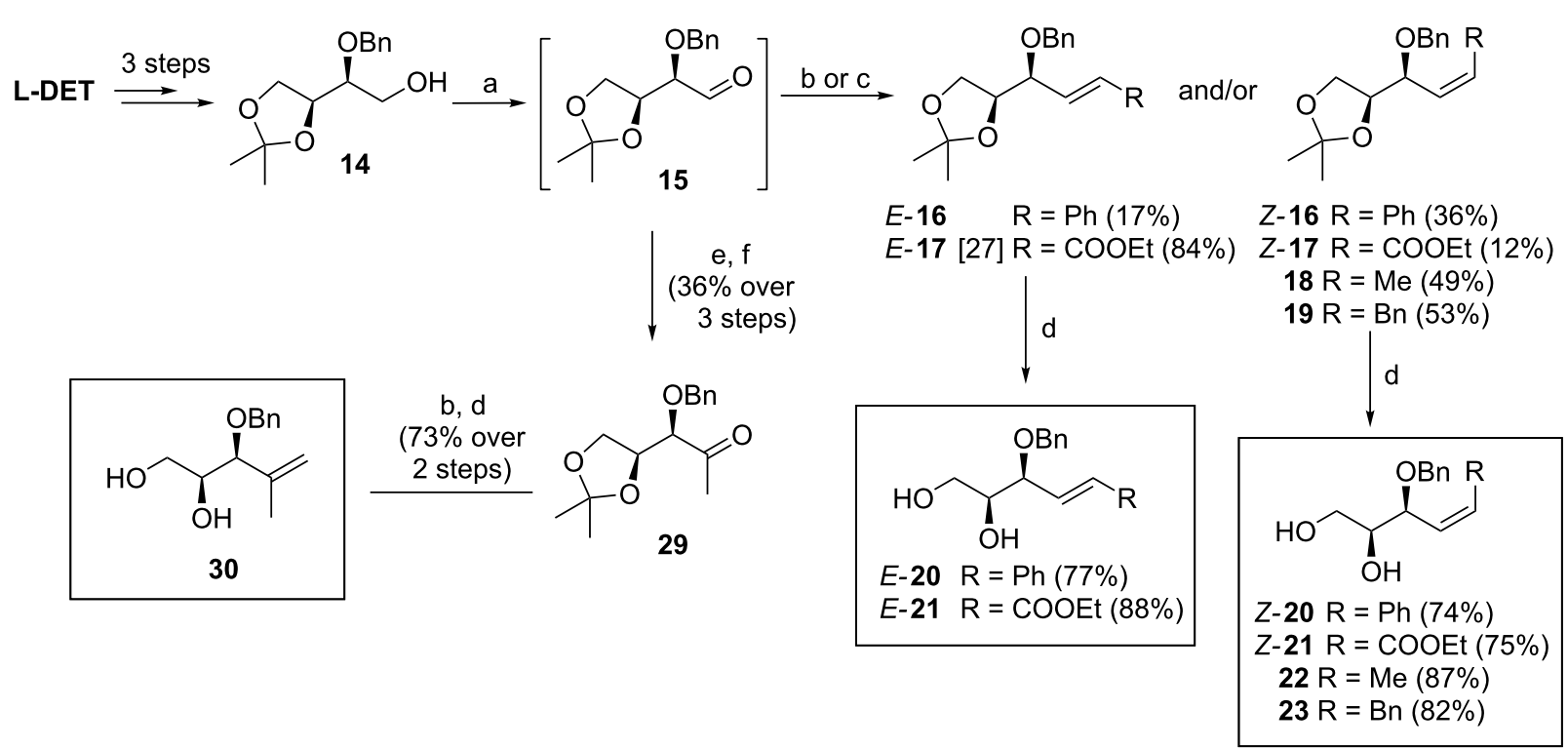

Scheme 2: Synthesis of alkenols $\mathbf{2 0 - 2 3}$ and 30. Reagents and conditions: a) lit. [31] $(\mathrm{COCl})_{2}, \mathrm{DMSO}, \mathrm{Et}_{3} \mathrm{~N}, \mathrm{CH}_{2} \mathrm{Cl}_{2},-78{ }^{\circ} \mathrm{C}$ to rt, $2 \mathrm{~h}$; b) Phosphonium salt, BuLi, THF, $0{ }^{\circ} \mathrm{C}$ to rt, overnight, MPLC; c) lit. [32] (EtO) ${ }_{2} \mathrm{POCH}_{2} \mathrm{CO}_{2} \mathrm{Et}, \mathrm{NaH}, \mathrm{THF}, 0{ }^{\circ} \mathrm{C}$ to rt, $\left.3 \mathrm{~h} ; \mathrm{d}\right) 60 \% \mathrm{AcOH}, 60{ }^{\circ} \mathrm{C}, 3 \mathrm{~h}$; e) $\mathrm{MeMgCl}$, $\mathrm{Et}_{2} \mathrm{O}, 0^{\circ} \mathrm{C}$ to rt, $1 \mathrm{~h}$; f) Dess-Martin periodinane, $\mathrm{CH}_{2} \mathrm{Cl}_{2}, 0^{\circ} \mathrm{C}, 1 \mathrm{~h}$. L-DET = L-dimethyl tartrate.

synthesis started from known threose 15 [31] followed by a common synthetic sequence comprising the olefination reaction and the hydrolysis of the acetonide protecting group. Thus, Horner-Wadsworth-Emmons olefination of aldehyde $\mathbf{1 5}$ furnished the corresponding separable mixture of $Z$ and $E$ alkenes $\mathbf{1 6}$ and 17. In the case of utilising stabilised phosphorane ylides, the Wittig reaction provided only $Z$ alkenes 18 and 19. Following acidic hydrolysis provided $\alpha$-O-benzyl substrates 20-23 in good yields. Additionally, the synthesis of substrate 30 with 1,1-disubstituted $\mathrm{C}-\mathrm{C}$ double bond was accomplished in
3 steps. The addition of methylmagnesium chloride to previously prepared threose 15, followed by Dess-Martin oxidation of the secondary alcohol gave methylketone 29. Subsequent Wittig olefination using (methylidene)triphenylphosphorane ylide and final hydrolysis of the acetonide provided the desired $\mathrm{C}_{5}$-substrate $\mathbf{3 0}$.

The synthesis of substrates 24-28 bearing an allylic hydroxy group is pictured in Scheme 3. At first, the ester group of previously prepared intermediate $E-\mathbf{1 7}$ was reduced using DIBAL-H<smiles></smiles>

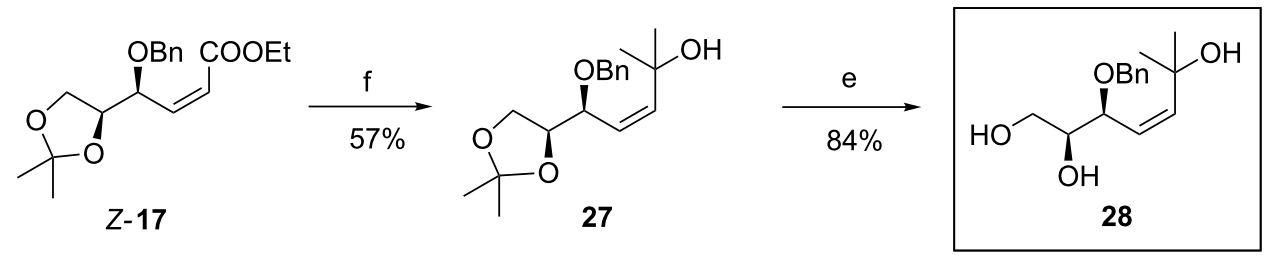

Scheme 3: Synthesis of alkenols 24-26 and 28. Reagents and conditions: a) lit. [32] DIBAL-H, $\mathrm{CH}_{2} \mathrm{Cl}_{2}$; b) $\mathrm{TBDPSCl}$ imidazole, $\mathrm{CH}_{2} \mathrm{Cl}{ }_{2}$, rt, overnight; c) $\mathrm{NaH}$, THF then Mel, rt, overnight; d) $\mathrm{FeCl}_{3} \cdot 6 \mathrm{H}_{2} \mathrm{O}, \mathrm{CHCl}_{3}, \mathrm{rt}, 1 \mathrm{~h}$ (for 25); e) $60 \% \mathrm{AcOH}, 60{ }^{\circ} \mathrm{C}, 3 \mathrm{~h} ; \mathrm{f}$ ) $\mathrm{MeLi}, \mathrm{Et}{ }_{2} \mathrm{O},-78{ }^{\circ} \mathrm{C}, 1 \mathrm{~h}$. TBDPSCl $=$ tertbutyldiphenylsilyl chloride. 
[32] providing the known allylic alcohol in very good yield. Following protection of the primary alcohol yielded fully protected alkene-tetraol and subsequent chemoselective removal of the acetonide protecting group in one pot led to substrates 24-26. The synthesis of substrate $\mathbf{2 8}$ bearing a tertiary allylic alcohol was performed in a two-step sequence. The addition of methyllithium to ester $Z-\mathbf{1 7}$ and following deprotection of the corresponding alcohol 27 with aqueous acetic acid afforded tetraol $\mathbf{2 8}$ in good yield.

Substrates syn-diols 33-35 (not bearing an $\alpha$ - $O$-protected group) were prepared in 2 steps starting from the aldehyde $\mathbf{3 1}$ using the Yamamoto's [33] sequential $O$-nitrosoaldol and Grignard addition process using different reagents (Scheme 4).

Thus, L-proline-catalysed oxidation of $\mathbf{3 1}$ with 2-nitrosotoluene gave the optically pure $O$-selective nitrosoaldol product $\mathbf{3 2}$, which underwent a reaction with the corresponding Grignard reagent in the presence of $\mathrm{CeCl}_{3} \cdot 2 \mathrm{LiCl}$ providing diols $\mathbf{3 3}-\mathbf{3 5}$ in good overall yields and high diastereoselectivity (d.r. $>20: 1$ ).

Additionally, allylic acetate $\mathbf{3 7}$ was obtained starting from 33 in a seven-step sequence in $30 \%$ overall yield. The acetonisation of hydroxy groups of the previously prepared diol 33, followed by $\mathrm{OsO}_{4}$ dihydroxylation of the $\mathrm{C}-\mathrm{C}$ double bond provided the corresponding diol in good yield. The resulting vicinal diol was then cleaved by sodium periodate to the corresponding aldehyde, which was immediately subjected to a Horner-Wadsworth-Emmons olefination using diethyl carbethoxyethylidenephopsphonate. Reduction of the resultant ester with DIBAL-H in dichloromethane afforded partially protected triol $\mathbf{3 6}$ in 39\% yield over five steps. Finally, acetylation of the primary hydroxy group and subsequent removal of the acetonide provided the target compound $\mathbf{3 7}$ in good yield (77\%).

Synthesis of the similar substrate rac-42 having two conjugated double bonds is shown in Scheme 5. The synthesis started from the known acetate 38, which was obtained by acetylation of commercially available non-3-ene-1-ol [34]. Epoxidation of acetate 38 with MCPBA in dichloromethane and subsequent acidic epoxide hydrolysis produced the syn-diol rac-39. The following protection of diol $\mathrm{rac-39}$ as its acetonide and the primary hydroxy group deprotection using sodium methoxide afforded alcohol rac-40 in good yield (43\% over 5 steps). Next, Swern oxidation of the primary hydroxy group provided the aldehyde, which was then transformed to diene derivative rac41 by Wadsforth-Emmons olefination using diethyl allylphosphonate. Final deprotection of the hydroxy groups furnished rac-42 in $63 \%$ yield.

In addition, enantiomerically pure substrate 43 was synthetised from D-glucose in 11 steps according to a protocol of Szewczyk [35] (Figure 3).

\section{Pd-catalysed cyclisations of unsaturated polyols}

Prepared substrates were then subjected to the Pd-catalysed transformation under several reaction conditions. At first, we tried the reaction conditions which were recently developed for the bicyclisation of $\alpha$-O-benzyl-protected polyols bearing a terminal alkene moiety [22]. Thus, the reactions incorporating

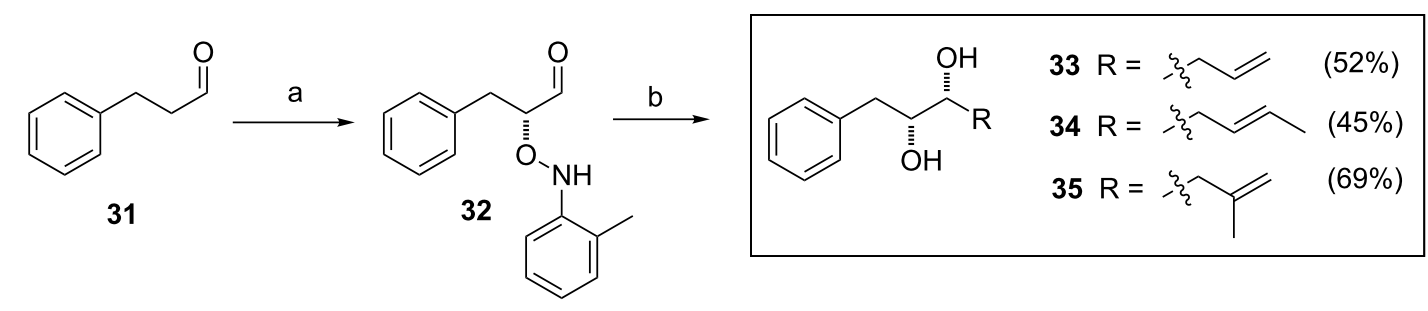<smiles>CC(C)[C@H]1OC(C)(C)O[C@@H]1C/C=C/CO</smiles>

Scheme 4: Synthesis of substrates 33-35, 37. Reagents and conditions: a) lit. [33] L-proline ( 0.25 equiv), 2-nitrosotoluene, $\left.\mathrm{CHCl}_{3},-18^{\circ} \mathrm{C} ; \mathrm{b}\right) \mathrm{RMgCl}$ $\mathrm{CeCl}_{3} \cdot 2 \mathrm{LiCl}$, THF, $-78^{\circ} \mathrm{C}$ to rt, overnight; c) acetone, PTSA, $3 \mathrm{~h}$, rt; d) $\mathrm{OsO}_{4}\left(0.01\right.$ equiv), NMO (2 equiv), pyridine, $5 \mathrm{~d}$, rt; e) $\mathrm{NalO}_{4}, \mathrm{MeOH}^{\circ} / \mathrm{H}_{2} \mathrm{O}, 3 \mathrm{~h}$, rt; f) NaH, (EtO) ${ }_{2} \mathrm{POCH}_{2} \mathrm{CO}_{2} \mathrm{Et}$, THF, $-20{ }^{\circ} \mathrm{C}$ to rt, $15 \mathrm{~min}$; g) DIBAL-H, $\mathrm{CH}_{2} \mathrm{Cl}_{2},-30{ }^{\circ} \mathrm{C}$ to $-10{ }^{\circ} \mathrm{C}, 45 \mathrm{~min}$; h) $\mathrm{Ac}_{2} \mathrm{O}$, pyridine, $\mathrm{CH}_{2} \mathrm{Cl}_{2}, 3 \mathrm{~h}, \mathrm{rt}$; i) $\mathrm{AcOH} /$ $\mathrm{H}_{2} \mathrm{O}, 3 \mathrm{~h}, 60^{\circ} \mathrm{C}$. PTSA = p-toluenesulfonic acid, $\mathrm{NMO}=\mathrm{N}$-methylmorpholine $\mathrm{N}$-oxide, DIBAL = diisobutylaluminium hydride. 


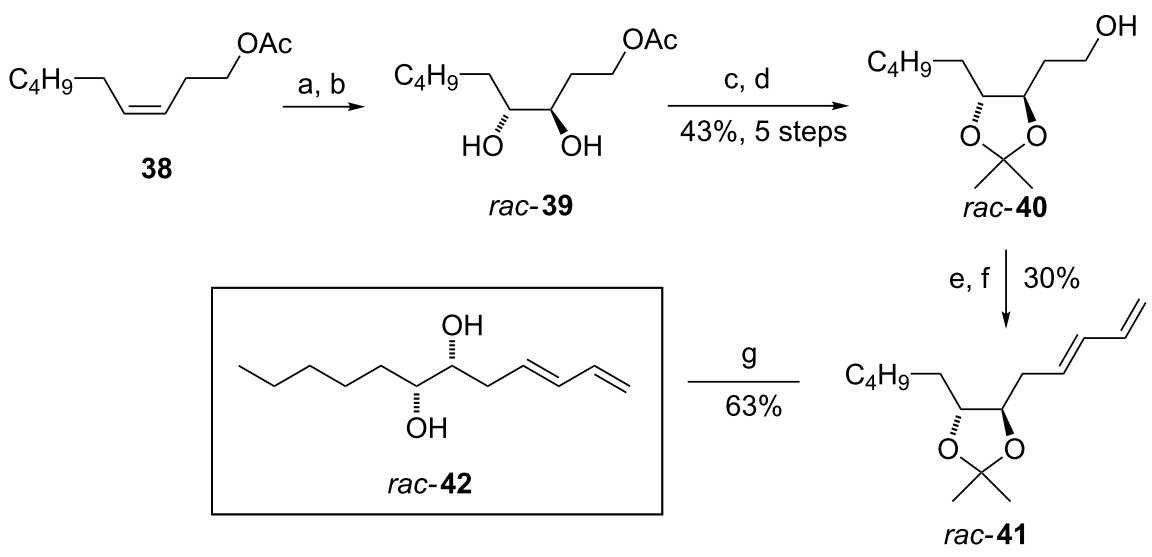

Scheme 5: Synthesis of rac-42. Reagents and conditions: a) MCPBA, $\mathrm{CH}_{2} \mathrm{Cl}_{2}, 0{ }^{\circ} \mathrm{C}$ to rt, $45 \mathrm{~min}$; b) TFA, $\mathrm{H}_{2} \mathrm{O}, \mathrm{THF}, 60{ }^{\circ} \mathrm{C}$ overnight, c) acetone, PTSA, $3 \mathrm{~h}$, rt; d) NaOMe, MeOH, 48 h, rt, $43 \%$ over 5 steps; e) $(\mathrm{COCl})_{2}$, DMSO, Et ${ }_{3} \mathrm{~N} \mathrm{CH}_{2} \mathrm{Cl}_{2},-78{ }^{\circ} \mathrm{C}$ to rt, 2 h; f) diethyl allylphosphonate, BuLi, THF, $0{ }^{\circ} \mathrm{C}$ to rt, overnight, $30 \%$ over 2 steps; g) $60 \% \mathrm{AcOH}, 60{ }^{\circ} \mathrm{C}, 3 \mathrm{~h}, 63 \%$. MCPBA $=m$-chloroperbenzoic acid, TFA $=$ trifluoacetic acid, PTSA $=$ p-toluenesulfonic acid.<smiles>C=C/C=C/CC(O)C(O)CO</smiles>

Figure 3: Structure of 43.

the $\mathrm{Pd}^{\mathrm{II}}-\mathrm{Pd}^{0}$ catalytic cycle (Scheme 6 ) were carried out using $\mathrm{PdCl}_{2}\left(0.1\right.$ equiv) as a catalyst, $\mathrm{CuCl}_{2}$ (3 equiv) as a reoxidant, $\mathrm{NaOAc}$ (3 equiv) as a buffer in $\mathrm{AcOH}$ at room temperature
(Table 1, Method A, see Supporting Information File 1 for full experimental data).

It is clear, that the chemoselectivity of the cyclisation reaction directly correlates to the nature of the $\mathrm{C}=\mathrm{C}$ bond of the substrate. Also, the configuration and the position of participating substituents have immense influence on the reaction output and the obtained results showed that the cyclisation reactions can progress through four different transformation pathways, yielding various types of products (I, II, III and IV).

Table 1: Pd-Catalysed cyclisations of unsaturated polyols.

Entry

2<smiles>C=CC([OH+])[C@@H](O)CO</smiles>

Method A

Method C
TBSO

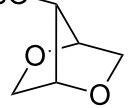

63

45 
Table 1: Pd-Catalysed cyclisations of unsaturated polyols. (continued)<smiles>C=CC(O)[C@@H](O)CO</smiles>

13
Method A

Complex mixture<smiles>C=CC[C@H](O)[C@H](O)Cc1ccccc1</smiles>

33
Method A

Method B

Method A<smiles>c1ccc(CC2OC3CCC2O3)cc1</smiles><smiles>Cc1ccc(Cc2ccccc2)o1</smiles>

$15(51), 25(52)$

65 (52)

$51+52$<smiles>CCOC(=O)C=CC([Se]C(=O)OCC)[C@@H](O)CO</smiles>

$E-21$<smiles>CCOC(=O)C=C1OC[C@H](O)[C@H]1OCc1ccccc1</smiles>

6<smiles>[R]OC/C=C/[C@H](O)[C@H](O)CO</smiles>

24-26<smiles>C=C[C@H]1OCC(O)[C@@H]1OCc1ccccc1</smiles>

$47+48$<smiles>CC(C)(O)C=C[C@@H](O)[C@@H](O)CO</smiles>

28<smiles>CC(=O)OC/C=C/C[C@H](O)[C@H](O)Cc1ccccc1</smiles>

37<smiles>C=C(C)C[C@H](O)[C@H](O)Cc1ccccc1</smiles>

Method A
Method A Method B
Method A

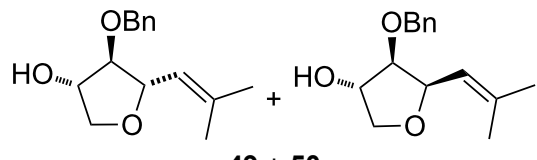

$49+50$<smiles>C=C[C@H]1CC(O)[C@@H](Cc2ccccc2)O1</smiles>

(n)

Method B $\mathrm{Pd}\left(\mathrm{PPh}_{3}\right)_{4}^{\mathrm{b}}$
$56+57$
$54(49 / 50,5: 3)$

$70(\mathbf{5 6 / 5 7}, 1: 3)$

$69(56 / 57,1: 3)$

$84(56 / 57,1: 3)$
35<smiles>C=C(C)[C@H](O)[C@H](O)CO</smiles>

30

9

10<smiles>C[C@]1(Cl)CO[C@H](Cc2ccccc2)C(O)C1</smiles>

53
33<smiles>CC1(C)COCC(O)[C@H]1OCc1ccccc1</smiles>

$(54), 35(55)$

$54+55$

Method B<smiles>OC1CO[C@H](CCl)[C@@H]1OCc1ccccc1</smiles>

\section{8}

aMethod A: $\mathrm{PdCl}_{2}$ (0.1 equiv), $\mathrm{CuCl}_{2}$ (3 equiv), $\mathrm{NaOAc}$ (3 equiv), $\mathrm{AcOH}$, rt.; method $\mathrm{B}: \mathrm{PdCl}_{2}\left(\mathrm{MeCN}_{2}(0.1\right.$ equiv), $\mathrm{BuLi}$ (2 equiv), CuCl 2 (3 equiv), LiCl (3 equiv), THF, rt; method C: $\mathrm{Pd}(\mathrm{OAc})_{2}$ (0.1 equiv), $\mathrm{Phl}(\mathrm{OAc})_{2}$ (2 equiv), $\mathrm{Me}_{4} \mathrm{~N}^{+} \mathrm{Cl}^{-}$(1 equiv), $\mathrm{NaOAc}\left(1\right.$ equiv), $\mathrm{AcOH}, \mathrm{rt}$. bit. [36-38] $\mathrm{Pd}(\mathrm{PPh})_{4}$ (0.1 equiv), THF, rt. 
Under these conditions (method A) the reactions of the simplest alkenols having a terminal alkene moiety and those with an $\alpha$-O-protected allylic system, i.e., 11 [23] (Table 1, entry 1 ) and 12 (Table 1, entry 2 ) provided corresponding bicycles of the type I. Likewise, the alkenediol $\mathbf{3 3}$ without $\alpha$-allylic hydroxy group provided bicyclic product $\mathbf{5 1}$, however, as a minor product in only $15 \%$ yield along with the furan compound $\mathbf{5 2}$ (Table 1, entry 4). The furan derivative $\mathbf{5 2}$ in this reaction was probably formed through a monocyclisation, followed by $\beta-H^{-}$elimination and aromatisation. In the case of substrate $\mathbf{1 3}$ having an unprotected $\alpha$-hydroxy group, the reaction provided only a mixture of unidentified products (Table 1, entry 3 ). These results are consistent with previous observations and it is evident that a protection of the $\alpha$-allylic hydroxy function is required for a successful bicyclisation reaction.

Next, we have also examined the compatibility of substrates having a symmetrically disubstituted $\mathrm{C}=\mathrm{C}$ bond in the cyclisation reactions. Unfortunately, butadienes rac-42 and $\mathbf{4 3}$ underwent uncontrollable transformations under these conditions providing a complex mixture of products. Similarly, the transformations of substrates 20,Z-21, 22 and $\mathbf{3 4}$ failed, while the reaction of $E$-21 (Table 1, entry 5) afforded surprisingly tetrahydrofuran derivative $\mathbf{4 6}$ as a product of a Wacker-type cyclisation.

Interestingly, the reactions of alkenols having an additional allylic OR group provided only products of type II. Thus, diastereomeric mixtures of vinyltetrahydrofurans 47,48 (Table 1, entry 6), 49, 50 (Table 1, entry 7) and 56, 57 (Table 1, entry 8) were formed starting from alkenols 24-26, 28 and 37. Formation of these products (type II) in this type of $\mathrm{Pd}^{\mathrm{II}}$-catalysed cyclisation [21,39-43] possibly involved an intramolecular Wacker-type reaction to form $\mathrm{Pd}^{\mathrm{II}}$-intermediate $\mathbf{E}$ and subsequent regeneration of the $\mathrm{Pd}^{\mathrm{II}}$-catalyst via cleavage of the C-OR bond (Scheme 6).

Surprisingly, the reaction of 1,1-disubstituted alkenes 30, 35 (Table 1, entries 10 and 9) provided only chlorinated tetrahydropyran (type III) and tetrahydrofuran (type IV) derivatives.

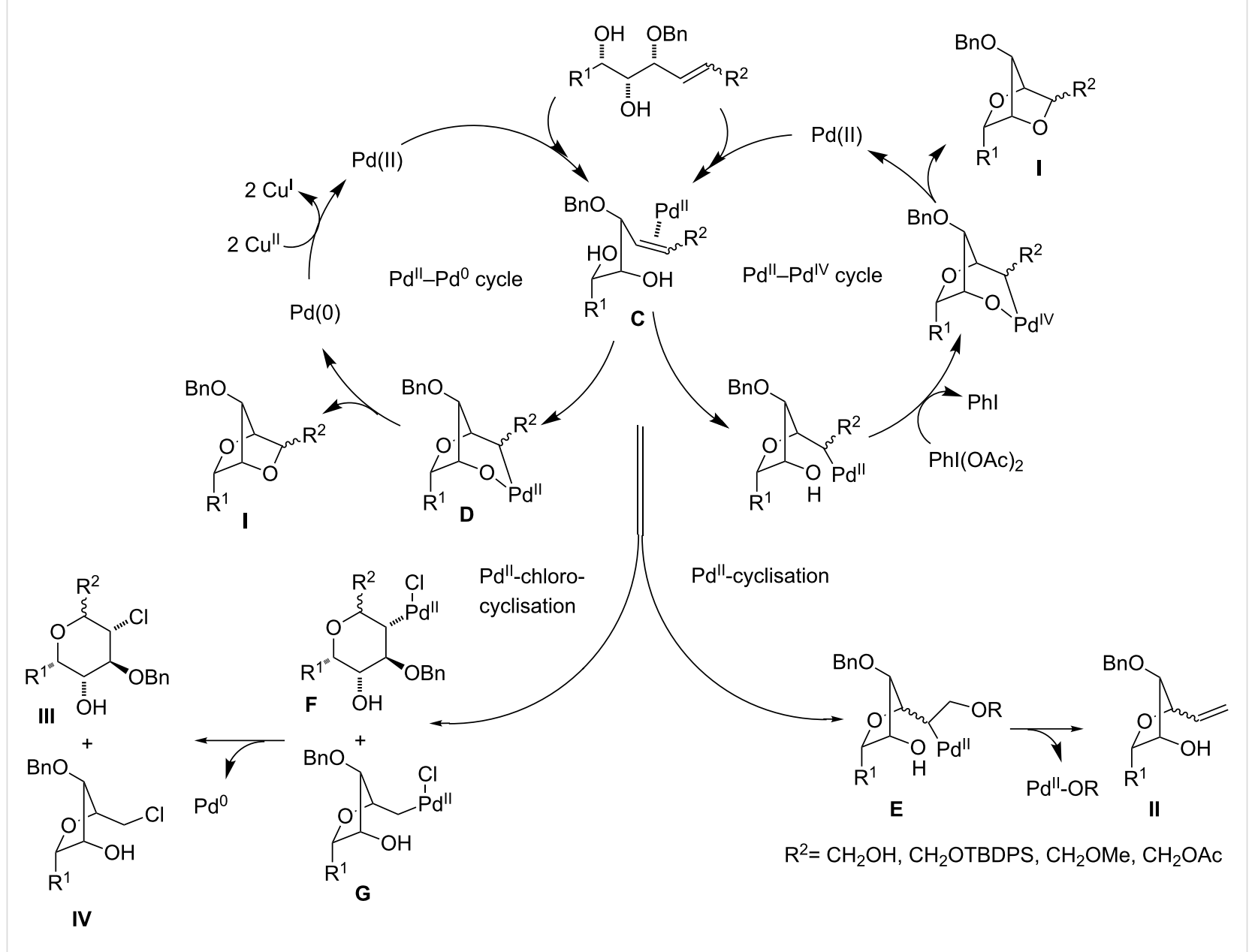

Scheme 6: Suggested mechanisms for $\mathrm{Pd}^{\mathrm{II}}-\mathrm{Pd}^{0}, \mathrm{Pd}^{\mathrm{II}}-\mathrm{Pd}^{\mathrm{IV}}$ and $\mathrm{Pd}^{\mathrm{Il}}$-chloro/cyclisation of unsaturated polyols. 
The chloroderivatives III and IV were probably formed from $\sigma$-alkyl Pd ${ }^{\mathrm{II}}$-complexes $\mathbf{F}$ and $\mathbf{G}$ by reductive elimination of $\mathrm{Pd}^{0}$ (Scheme 6). Additionally, the X-ray analysis [44] of $\mathbf{5 3}$ confirmed the absolute configuration and structure of the sixmembered heterocycle (Figure 4).

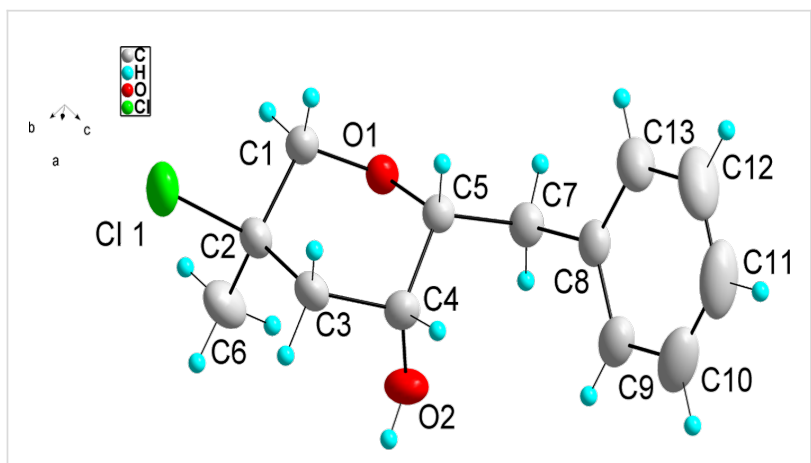

Figure 4: An ORTEP [44] view of crystal and molecular structure of 53.

Recently, Wolfe reported a tetrahydrofuran-forming reaction via Pd-catalysed carboetherification [45-49] under strong basic conditions in the presence of a phosphine ligand. In order to enhance the ligand affinity of the hydroxy group in the formation of $\sigma$-palladium ${ }^{\text {II }}$-complex D (Scheme 6), we have decided to adopt the described conditions and to examine the transformation of alkenols in the presence of $\mathrm{PdCl}_{2}(\mathrm{MeCN})_{2}$, butyllithium and $\mathrm{LiCl}$ (method B). Unfortunately, these experiments in most cases did not afford any cyclisation products and reactions of non-terminal olefinic substrates 20-23, 34, rac-42 and 43 provided only a complex mixture of inseparable products. However, terminal olefins $\mathbf{3 0}$ and threo-9 underwent chlorocyclisation most probably due to the presence of an excess of chloride anions (Table 1, entries 10 and 11). Interestingly, this chlorocyclisation reaction proceeded with high trans-diastereoselectivity, which is in accordance with Wolfe's TS model [17,18]. In both cases, only 2,3-trans diastereomers 55 and 58 were isolated in good yields. In addition, this reaction represents a new synthetic access to the 3-hydroxy-2,3-trans-tetrahydrofuran skeleton and is complementary to the known $\mathrm{X}^{+}$-mediated cyclisation methodology producing exclusively 2,3-cis-diastereomer [14,15,50,51].

Based on the published findings, we have also examined the cyclisation reactions incorporating the $\mathrm{Pd}{ }^{\mathrm{II}}-\mathrm{Pd}^{\mathrm{IV}}$ catalytic cycle $[52,53]$ (Scheme 6). The experiments were carried out using $\mathrm{Pd}(\mathrm{OAc})_{2}$ salt as a catalyst, $\mathrm{PhI}(\mathrm{OAc})_{2}$ as reoxidant, $\mathrm{AcONa}$ and $\mathrm{Me}_{4} \mathrm{~N}^{+} \mathrm{Cl}^{-}$as buffer in $\mathrm{AcOH}$ (method C). Unfortunately, all reactions and their modifications (temperature, solvents: $\mathrm{AcOH}, \mathrm{AcOH}-\mathrm{H}_{2} \mathrm{O}$, NMP, DMF, $\mathrm{MeOH}$, THF, Et ${ }_{2} \mathrm{O}, \mathrm{DCM}$, $\mathrm{CHCl}_{3}$ ) did not provide cyclisation products and only complex mixtures of $\beta-H^{-}$-elimination and consequential products were observed. Only one exception to previously unpleasant findings was a reaction of $O$-silyl-protected triol 12, which provided the bicycle $\mathbf{4 5}$ but only in a decreased yield of $40 \%$ (Table 1, entry 2).

To show the usefulness of such cyclisation products, we have investigated the possibility of employing prepared tetrahydrofuran derivatives bearing suitable moieties in the next cyclisation step (Scheme 7).<smiles>C[C@]1(CCl)OCC(O)[C@@H]1Br</smiles>

55<smiles>O[C@H]1CO[C@H](CCl)[C@@H]1OCc1ccccc1</smiles>

58

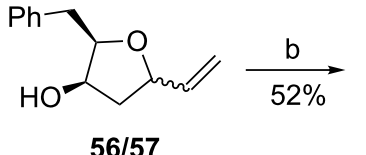

$(1: 3)$
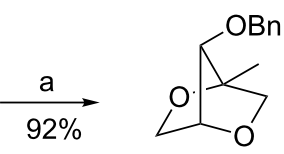

59

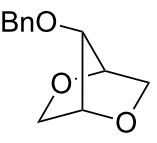

44

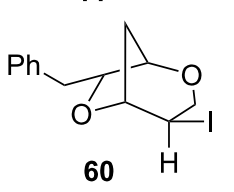

60
Scheme 7: Bicyclisation of 55-58. Reagents and conditions: a) $\mathrm{NaH}$, DMF, $50{ }^{\circ} \mathrm{C}, 2 \mathrm{~h}$; b) $\mathrm{I}_{2}, \mathrm{CH}_{3} \mathrm{CN}$, rt, overnight.

Gratifyingly, the chloromethyltetrahydrofurans $\mathbf{5 5}$ and $\mathbf{5 8}$ were both transformed into the bicyclic products 59 and $\mathbf{4 4}$ by treatment with sodium hydride in DMF. Also, this transformation step has approved the relative configurations of substituents on the tetrahydrofuran ring. Interestingly, an iodo-cyclisation reaction of a 1:3 diastereomeric mixture of vinyltetrahydrofurans $\mathbf{5 6}$ and $\mathbf{5 7}$ in acetonitrile provided only one corresponding product derived from 56. Thus, pure $(4 R, 7 R)-4,7$-disubstituted 2,6-dioxabicyclo[3.2.1] octane $\mathbf{6 0}$ was isolated in 52\% yield. The trans arrangement of the substituents at $\mathrm{C} 4 / \mathrm{C} 7$ in the product of the 6-endo-trig cyclisation was determined by means of ${ }^{1} \mathrm{H}$ NMR and NOE interactions.

In conclusion, we have also shown the possibility to construct interesting bicyclic intermediates in a 2 step sequence combining the $\mathrm{Pd}^{\mathrm{II}}$-catalysed cyclisation [36-40] or $\mathrm{Pd}^{0}$-allylic substitution $[42,43]$ of alkenols having an allylic OR group and additional halocyclisation.

\section{Conclusion}

In summary, we have developed the syntheses of several unsaturated alcohols. The chiral alkenols 20-28, 34-37 and 43 represent useful C5-C12 chain building blocks. 
The stereoselective $\mathrm{Pd}^{\mathrm{II}}-\mathrm{Cu}^{\mathrm{II}}$-catalysed cyclisation [22] and its substrate scope has been investigated. The bicyclisation reaction appears to be applicable only to terminal olefinic substrates, while the reaction of alkenols bearing nonterminal and/or disubstituted olefins did not provide bicyclisation products. Moreover, alkenes having both an allylic OR group and a hydroxylated tether underwent intramolecular Wacker-type cyclisation affording corresponding vinyltetrahydrofurans, which constitute useful intermediates for the synthesis of naturally occurring tetrahydrofuran derivatives.

We have also explored the Pd-cyclisation of unsaturated polyols in the presence of a strong base or a high oxidation state palladium catalyst. The $\mathrm{Pd}^{\mathrm{II}}-\mathrm{Pd}^{\mathrm{IV}}$-catalysed transformation toward the bicyclisation product proceeded only on the $O$-silylprotected triol 12. The $\mathrm{Pd}^{\mathrm{II}}$-cyclisation of terminal olefinic substrates in the presence of $\mathrm{BuLi}$ and $\mathrm{LiCl}$ provided selectively 5-exo-trig cyclisation products with excellent 2,3-trans diastereoselectivity.

Finally, we have also proposed a synthetic access to the dioxaheptane core of natural $\mathrm{C}_{15}$ acetogenins and dioxaoctane, a substructure of the macrolide-polyether antibiotic sorangicin A and aurovertins. Thus, Pd-catalysed cyclisation of appropriate alkenols to tetrahydrofurans and subsequent iodo-cyclisation yielded properly substituted 2,5-dioxabicyclo[2.2.1] heptane and 2,6-dioxabicyclo[3.2.1] octane, respectively with defined stereochemistry and excellent diastereoselectivity. The further synthetic studies toward ocellenynes are currently underway.

\section{Supporting Information}

\section{Supporting Information File 1}

Mechanisms, general information, experimental procedures and spectroscopic data for all new compounds.

[http://www.beilstein-journals.org/bjoc/content/ supplementary/1860-5397-10-216-S1.pdf]

\section{Supporting Information File 2}

${ }^{1} \mathrm{H}$ NMR and ${ }^{13} \mathrm{C}$ NMR spectra of selected compounds. [http://www.beilstein-journals.org/bjoc/content/ supplementary/1860-5397-10-216-S2.pdf]

\section{Supporting Information File 3}

X-ray crystal structure analysis of $\mathbf{5 3}$.

[http://www.beilstein-journals.org/bjoc/content/ supplementary/1860-5397-10-216-S3.pdf]

\section{Acknowledgements}

This work was supported by Slovak Grant Agencies (VEGA No. 1/0488/14, APVV-0203-10, LPP-0071-09 and ASFU, Bratislava, ITMS projects No. 26240120001, 26240120025).

\section{References}

1. Gracza, T.; Jäger, V. Synlett 1992, 191-193. doi:10.1055/s-1992-21309

2. Cao, S.-G.; Wu, X.-H.; Sim, K.-Y.; Tan, B. K. H.; Pereira, J. T.; Goh, S.-H. Tetrahedron 1998, 54, 2143-2148. doi:10.1016/S0040-4020(97)10422-7

3. Malmstrøm, J.; Christophersen, C.; Barrero, A. F.; Oltra, J. E.; Justicia, J.; Rosales, A. J. Nat. Prod. 2002, 65, 364-367. doi:10.1021/np0103214

4. Howard, B. H.; Raistrick, H. Biochem. J. 1949, 44, 227-233.

5. Beutler, J. A.; Hilton, B. D.; Clark, P.; Tempesta, M. S.; Corley, D. G. J. Nat. Prod. 1988, 51, 562-566. doi:10.1021/np50057a018

6. Schulte, G. R.; Chung, M. C. H.; Scheuer, P. J. J. Org. Chem. 1981, 46, 3870-3873. doi:10.1021/jo00332a022

7. Wright, A. D.; König, G. M.; de Nys, R.; Sticher, O. J. Nat. Prod. 1993, 56, 394-401. doi:10.1021/np50093a012

8. Jansen, R.; Wray, V.; Irschik, H.; Reichenbach, H.; Höfle, G. Tetrahedron Lett. 1985, 26, 6031-6034. doi:10.1016/S0040-4039(00)95117-7

9. Baldwin, C. L.; Weaver, L. C.; Brooker, R. M.; Jacobsen, T. N.; Osborne, C. E., Jr.; Nash, H. A. Lloydia 1964, 27, 88-95.

10. Osselton, M. D.; Baum, H.; Beechey, R. B. Biochem. Soc. Trans. 1974, 200-202.

11. Mulheirn, L. J.; Beechey, R. B.; Leworthy, D. P.; Osselton, M. D. J. Chem. Soc., Chem. Commun. 1974, 874-876. doi:10.1039/C39740000874

12. Wang, F.; Luo, D.-Q.; Liu, J.-K. J. Antibiot. 2005, 58, 412-415. doi:10.1038/ja.2005.53

13. Lai, S.; Matsunaga, K.; Shizuri, Y.; Yamamura, S. Tetrahedron Lett. 1990, 31, 5503-5506. doi:10.1016/S0040-4039(00)97883-3

14. Cardillo, G.; Orena, M. Tetrahedron 1990, 46, 3321-3408. doi:10.1016/S0040-4020(01)81510-6

15. Cardillo, G.; Orena, M. Formation of C-O bonds by cyclization onto olefinic double bonds forming lactones and ethers. In Houben-Weyl, 4th ed.; Helmchen, G.; Hoffmann, R.; Mulzer, J., Eds.; Thieme: Stuttgart, 1995; Vol. E21e, pp 4698-4817.

16. Wolfe, J. P. Synthesis of saturated heterocycles via metal-catalyzed alkene carboamination or carboalkoxylation reactions. In Synthesis of Heterocycles via Metal-Catalyzed Reactions that Generate One or More Carbon-Heteroatom Bonds; Wolfe, J. P., Ed.; Topics in Heterocyclic Chemistry, Vol. 32; Springer: Berlin, 2013; pp 1-38.

17. Wolfe, J. P. Eur. J. Org. Chem. 2007, 571-582. doi:10.1002/ejoc.200600767

18. Wolfe, J. P. Synlett 2008, 2913-2937. doi:10.1055/s-0028-1087339

19. Gracza, T. Intramolecular oxycarbonylation in stereoselective synthesis. In Stereoselective Synthesis of Drugs and Natural Products; Andrushko, V.; Andrushko, N., Eds.; Wiley: Hoboken, New Jersey, 2013; Vol. 1, pp 421-440. doi:10.1002/9781118596784.ssd015

20. Doháňošová, J.; Gracza, T. Molecules 2013, 18, 6173-6192. doi:10.3390/molecules18066173

21. Muzart, J. J. Mol. Catal. A: Chem. 2010, 319, 1-29. doi:10.1016/j.molcata.2009.12.001 
22. Babjak, M.; Remeň, L.; Szolcsányi, P.; Zálupský, P.; Mikloš, D.; Gracza, T. J. Organomet. Chem. 2006, 691, 928-940. doi:10.1016/j.jorganchem.2005.10.036

23. Babjak, M.; Remeň, L.; Karlubíková, O.; Gracza, T. Synlett 2005, 1609-1611. doi:10.1055/s-2005-869840

24. Palík, M.; Karlubíková, O.; Lásiková, A.; Kožíšek, J.; Gracza, T. Eur. J. Org. Chem. 2009, 709-715. doi:10.1002/ejoc.200801070

25. Palík, M.; Karlubíková, O.; Lackovičová, D.; Lásiková, A.; Gracza, T. Tetrahedron 2010, 66, 5244-5249. doi:10.1016/j.tet.2010.04.074

26. Bravo, F.; Kassou, M.; Castillón, S. Tetrahedron Lett. 1999, 40, 1187-1190. doi:10.1016/S0040-4039(98)02561-1

27. Fürstner, A.; Jumbam, D.; Teslic, J.; Weidmann, H. J. Org. Chem. 1991, 56, 2213-2217. doi:10.1021/jo00006a047

28. Koppenhoefer, B.; Walser, M.; Schröter, D.; Häfele, B.; Jäger, V. Tetrahedron 1987, 43, 2059-2064. doi:10.1016/S0040-4020(01)86787-9

29. Jäger, V.; Schröter, D.; Koppenhoefer, B. Tetrahedron 1991, 47, 2195-2210. doi:10.1016/S0040-4020(01)96130-7

30. Babjak, M.; Zálupský, P.; Gracza, T. ARKIVOC 2005, No. v, 45-57.

31. Sánches-Sancho, F.; Valverde, S.; Herradón, B. Tetrahedron: Asymmetry 1996, 7, 3209-3246. doi:10.1016/0957-4166(96)00424-7

32. Chandrasekhar, S.; Parida, B. B.; Rambabu, C. J. Org. Chem. 2008, 73, 7826-7828. doi:10.1021/jo801377s

33. Jiao, P.; Kawasaki, M.; Yamamoto, H. Angew. Chem., Int. Ed. 2009, 48, 3333-3336. doi:10.1002/anie.200900682

34. Prat, I.; Font, D.; Company, A.; Junge, K.; Ribas, X.; Beller, M.; Costas, M. Adv. Synth. Catal. 2013, 355, 947-956. doi:10.1002/adsc.201200938

35. Jarosz, S.; Skóra, S.; Szewczyk, K. Tetrahedron: Asymmetry 2000, 11 , 1997-2006. doi:10.1016/S0957-4166(00)00135-X

36. Trost, B. M.; Tenaglia, A. Tetrahedron Lett. 1988, 29, 2927-2930. doi:10.1016/0040-4039(88)85049-4

37. Passiniemi, M.; Koskinen, A. M. P. Tetrahedron Lett. 2008, 49, 980-983. doi:10.1016/j.tetlet.2007.12.014

38. Roulland, E. Angew. Chem., Int. Ed. 2008, 47, 3762-3765. doi:10.1002/anie.200800585

39. Uenishi, J.; Ohmi, M.; Ueda, A. Tetrahedron: Asymmetry 2005, 16, 1299-1303. doi:10.1016/j.tetasy.2005.02.006

40. Uenishi, J.; Ohmi, M. Angew. Chem., Int. Ed. 2005, 44, 2756-2760. doi:10.1002/anie.200500029

41. Kawai, N.; Lagrange, J.-M.; Ohmi, M.; Uenishi, J. J. Org. Chem. 2006, 71, 4530-4537. doi:10.1021/jo060415o

42. Kawai, N.; Lagrange, J.-M.; Uenishi, J. Eur. J. Org. Chem. 2007, 2808-2814. doi:10.1002/ejoc.200601103

43. Kawai, N.; Hande, S. M.; Uenishi, J. Tetrahedron 2007, 63, 9049-9056. doi:10.1016/j.tet.2007.06.081

44. CCDC 963459 (for compound 53) contains the supplementary crystallographic data for this paper. These data can be obtained free of charge from The Cambridge Crystallographic Data Centre via http://www.ccdc.cam.ac.uk/data_request/cif

45. Wolfe, J. P.; Rossi, M. A. J. Am. Chem. Soc. 2004, 126, 1620-1621. doi:10.1021/ja0394838

46. Hay, M. B.; Hardin, A. R.; Wolfe, J. P. J. Org. Chem. 2005, 70, 3099-3107. doi:10.1021/jo050022+

47. Hay, M. B.; Wolfe, J. P. J. Am. Chem. Soc. 2005, 127, 16468-16476. doi:10.1021/ja054754v

48. Hay, M. B.; Wolfe, J. P. Tetrahedron Lett. 2006, 47, 2793-2796. doi:10.1016/j.tetlet.2006.02.066
49. Ward, A. F.; Wolfe, J. P. Org. Lett. 2010, 12, 1268-1271. doi:10.1021/ol1001472

50. Chamberlin, A. R.; Mulholland, R. L., Jr.; Kahn, S. D.; Hehre, W. J. J. Am. Chem. Soc. 1987, 109, 672-677. doi:10.1021/ja00237a006

51. Kahn, S. D.; Hehre, W. J. J. Am. Chem. Soc. 1987, 109, 666-671. doi:10.1021/ja00237a005

52. Muñiz, K. Angew. Chem., Int. Ed. 2009, 48, 9412-9423. doi:10.1002/anie.200903671

53. Xu, L.-M.; Li, B.-J.; Yang, Z.; Shi, Z.-J. Chem. Soc. Rev. 2010, 39, 712-733. doi:10.1039/b809912j

\section{License and Terms}

This is an Open Access article under the terms of the Creative Commons Attribution License

(http://creativecommons.org/licenses/by/2.0), which permits unrestricted use, distribution, and reproduction in any medium, provided the original work is properly cited.

The license is subject to the Beilstein Journal of Organic Chemistry terms and conditions:

(http://www.beilstein-journals.org/bjoc)

The definitive version of this article is the electronic one which can be found at: doi: $10.3762 /$ bjoc. 10.216 